\title{
Comparison of Effects of Uranium and Americium on Bioluminescent Bacteria
}

\author{
Tatiana V. Rozhko ${ }^{a *}$, Nadezhda S. Kudryasheva, \\ Maria A. Aleksandrovab ${ }^{b}$ Lidia G. Bondareva ${ }^{a}$, \\ Alexander Ya. Bolsunovsky and Galina V. Vydryakova ${ }^{a}$ \\ ${ }^{a}$ Institute of Biophysics of Siberian Branch of Russian Academy of Sciences, \\ Akademgorodok, Krasnoyarsk, 660036 Russia \\ ${ }^{b}$ Siberian Federal University, Svobodny av. 79, Krasnoyarsk, 660041 Russia ${ }^{1}$
}

Received 1.09.2007, received in revised form 1.12.2007, accepted 15.01.2008

Effect of $\mathrm{UO}_{2}\left(\mathrm{NO}_{3}\right)_{2}$ on bioluminescent bacteria P.Phosphoreum was studied. It was compared with the effect of solutions of the more active radionuclide - ${ }^{241} \mathrm{Am}\left(\mathrm{NO}_{3}\right)_{3}$ studied earlier (Rozhko et al., 2007). Bioluminescence inhibition was observed under uranyl concentrations exceeding $10^{-7} \mathrm{M}(30 \mathrm{~Bq} / \mathrm{ll})$; and bioluminescence activation was not observed under all radionuclide concentrations and exposure times in the experiment. Effect of uranyl was attributed to chemical component of its impact, not radiation one. It was shown that solutions of Americium were detoxified by humic substances $(0.25 \mathrm{mg} / \mathrm{ml})$, but solutions of uranyl-are not.

Keywords: Radiotoxicity, biomonitoring, bioluminescence.

\section{Introduction}

Increase of radioactive contamination in the environment makes the effects of lowlevel radiation on living organisms very important. Detailed investigations of the effect of low dose radiation on living organisms were conducted using simple assay systems such as microorganisms, bacteria, plant and mammal cells, tissues of laboratory mice, drosophila flies, freshwater crustaceans, etc (Lyutykh, 1998; Nikolsky and Koterov, 1999; Spitkovsky, 1999; Koterov and Nikolsky, 1999). Assay systems based on luminous bacteria are good candidates for such investigations. Bacterial bioluminescent assays are widely used to monitor environmental toxicity (Kratasyuk and Gitelson, 1987). The tested parameter is luminescent intensity of bacteria, which can be easily measured instrumentally. The advantages of the bioluminescent assays are their rapidity, sensitivity, simplicity, and availability of the devices for toxicity registration (Kratasyuk and Gitelson, 1987; Kudryasheva et al., 1998).

Bioluminescent bacteria have been used as a bioassay for almost a half of a century. The bioassay was described in its current form in 1969 (Grabert and Kossler, 1997). Later, it was modified by different researchers and adapted for their specific purposes; numerous applications of the bacterial bioassay are known (Stom et al., 1992; Wood and Gruber, 1996; Natecz-Jawecki et al., 1997; Roda et

\footnotetext{
Corresponding author E-mail address: gutniktv72@mail.ru (C) Siberian Federal University. All rights reserved
} 
al., 2004; Kudryasheva, 2006). In 1990 the in vitro assay based on bioluminescent system of enzymatic coupled reactions was suggested as a toxicity assay (Kudryasheva et al., 1998); its applications were developed (Kudryasheva et al., 2002, 2003). Now, the bioluminescent ecological assay is a traditional and important biotechnological application of the bioluminescence phenomenon (Roda et al., 2004).

General radiotoxicity was already investigated using bioluminescence of the recombinant Escherichia coli strains exposured to gamma-ray irradiation (Min et al., 2003). Bioluminescent bioassays have been already used to study the effect of low-level alpharay irradiation in (Rozhko et al., 2007). In this work, three bioluminescent assay systems were applied: intact bacteria, lyophilized bacteria, and bioluminescent system of coupled enzyme reactions. Solutions of ${ }^{241} \mathrm{Am}\left(\mathrm{NO}_{3}\right)_{3}$ were used in this paper as a source of $\alpha$-radiation. The activation processes were shown to predominate in all three bioluminescent assay systems subjected to short-term exposure (to 20-55 hr) and inhibition processes - in the systems subjected to longer-term exposure to radiation. Fig. 1 demonstrates the effect of ${ }^{241} \mathrm{Am}^{3+}$ on the bioluminescent intact bacteria as an example. The

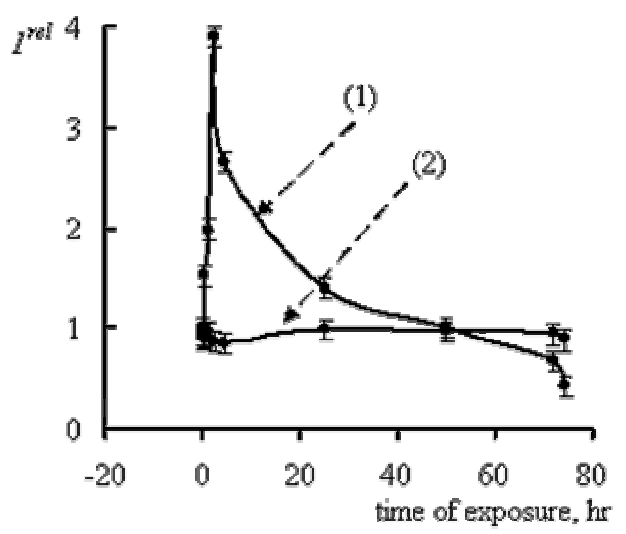

Fig. 1 Bioluminescent intensity $\left(\mathrm{I}^{\mathrm{rel}}\right)$ vs time of exposure ( $\mathrm{t}$, hours) in solutions of ${ }^{241} \mathrm{Am}^{3+}$ $\left(\mathrm{C}=2 \cdot 10^{-10} \mathrm{M}, \mathrm{A}=6000 \mathrm{~Bq} / \mathrm{l}\right)(1)$ and $\mathrm{Eu}^{3+}$ $\left(\mathrm{C}=2 \cdot 10^{-10} \mathrm{M}\right)(2)$, from: (Rozhko et al., 2007) absence of the effect of nonradiative Americium analogue - Eu - under similar experimental conditions is demonstrated, too. The comparison of two curves here brings up the conclusion that the effect of ${ }^{241} \mathrm{Am}^{3+}$ was caused by its radiation component. In the paper mentioned (Rozhko et al., 2007), the impact of ${ }^{241} \mathrm{Am}^{3+}$ was shown to depend on its concentration, the level of organization and integrity of bioluminescent assay system. Bioluminescent assay system in vivo (bioluminescent bacteria) was found to be more sensitive to ${ }^{241} \mathrm{Am}^{3+}$ (down to $10^{-11} \mathrm{M}, 300$ $\mathrm{Bq} / \mathrm{l})$.

The effects of radionuclides of various $\alpha$ activity on the bioluminescent assay system are of interest. In this paper, two $\alpha$-radionuclides of different specific activity were chosen - Uranium and Americium. The following data compare radioactivity of these radionuclides: the activity of $3000 \mathrm{~Bq} / 1$ corresponds to $10^{-3} \mathrm{M}$ solution of Uranium and $10^{-10} \mathrm{M}$ solution of Americium. The purpose of this study was to monitor the effect of Uranium on the bioluminescent bacteria, to compare the effects of Uranium and Americium, and to compare the detoxification activity of humic substances in the solutions of these radionuclides.

\section{Materials and Methods}

\section{Objects}

Cell suspension of 16-h P.phosphoreum 1883 IBSO culture from the Collection of Luminous Bacteria CCIBSO was applied as a bioassay system. Solutions of $\mathrm{UO}_{2}\left(\mathrm{NO}_{3}\right)_{2}$ of basic concentration $10^{-3} \mathrm{M}$ in $1.1 \mathrm{M} \mathrm{NaNO}_{3}$ ( $\left.\mathrm{pH} 6.5-7.0\right)$ were used as a source of ionizing radiation. The activity of this solution was $3000 \mathrm{~Bq} / \mathrm{l}$. Bioluminescent bacteria were exposed to solutions of $\mathrm{UO}_{2}\left(\mathrm{NO}_{3}\right)_{2}$ of the following concentrations: $10^{-3} \mathrm{M}, 10^{-4} \mathrm{M}, 10^{-5} \mathrm{M}$, $10^{-7} \mathrm{M}, 10^{-9} \mathrm{M}, 10^{-10} \mathrm{M}$, and $10^{-11} \mathrm{M}$.

To investigate the effect of uranyl nitrate, the radioactive and control samples were prepared. 
Radioactive samples: solutions of $\mathrm{UO}_{2}\left(\mathrm{NO}_{3}\right)_{2}$ in $1.1 \mathrm{M} \mathrm{NaNO}_{3}$ were added to bioluminescent bacteria. Control samples: $1.1 \mathrm{M} \mathrm{NaNO}_{3}$ solutions were added to bioluminescentbacteria. Radioactive and control samples were maintained at constant temperature $4^{\circ} \mathrm{C}$ for 25 hours. Periodically, the test samples (radioactive and control) were prepared and the bioluminescent intensity was recorded at $20^{\circ} \mathrm{C}$ applying the standard procedure (Kuznetsov et al., 1996). Measurements were carried out in 0.5-10 hr with increasing time-intervals between samplings.

Compositions of the test samples (radioactive or control) were following: $50 \mu \mathrm{l}$ of radioactive (or control) samples and $500 \mu \mathrm{l}$ of the $3 \% \mathrm{NaCl}$ solution.

The Gumat-80 ("Gumat", Irkutsk) was used as a source of humic substances. It was produced by non-extracting treatment of coal (Levinsky, 2000).

\section{Evaluation of radiotoxicity}

of the test samples

Kinetics of bioluminescence signal was studied using a CL3606 Biochemiluminometer (SKTB "Nauka", Russia). Relative bioluminescent intensity $I^{r e l}$ was calculated:

where:

$$
I^{r e l}=\frac{I_{\text {rad }}}{I_{\text {contr }}},
$$

$I_{\text {rad }}$ is bioluminescence intensity in the radioactive test sample,

$I_{\text {contr }}$ is bioluminescence intensity in the control test sample.

Values of $I^{\text {rel }}$ were plotted vs time of exposure to radionuclides. $I^{\text {rel }}$ was evaluated in the absence and in the presence of $0.25 \mathrm{mg} / \mathrm{ml}$ humic substances in solutions of $\mathrm{UO}_{2}\left(\mathrm{NO}_{3}\right)_{2}\left(10^{-3}-10^{-11}\right.$ $\mathrm{M}), \mathrm{Am}\left(\mathrm{NO}_{3}\right)_{3}\left(2 \cdot 10^{-10}-10^{-13} \mathrm{M}\right)$, and $\mathrm{Eu}\left(\mathrm{NO}_{3}\right)_{3}$ $\left(10^{-3}-10^{-13} \mathrm{M}\right)$.
3. Detoxification of radioactive solutions

by humic substances

Values of $I^{\text {rel }}$ vs time of exposure to $\mathrm{Am}\left(\mathrm{NO}_{3}\right)_{3}$ or $\mathrm{UO}_{2}\left(\mathrm{NO}_{3}\right)_{2}$ were compared in the absence and presence of humic substances $(\mathrm{C}=0,25 \mathrm{mg} / \mathrm{ml})$.

\section{Results and Discussion}

It was found that only higher concentrations of $\mathrm{UO}_{2}\left(\mathrm{NO}_{3}\right)_{2}\left(10^{-3}-10^{-7} \mathrm{M}\right)$ inhibited $\left(I^{r e l}<1\right)$ bioluminescence. Dependence of $I^{\text {rel }}$ vs time of exposure is presented in Fig. 2(A) for three concentrations ofUranium as an example. Thus, the effect of Uranium on the bioluminescent bacteria was observed at much higher concentrations than that of Americium (Rozhko et al., 2007): $>10^{-5} \mathrm{M}$ $(30 \mathrm{~Bq} / \mathrm{l})$ and $>10^{-11} \mathrm{M}(300 \mathrm{~Bq} / \mathrm{l})$ respectively. Second difference is the absence of activation period under all concentrations of $\mathrm{UO}_{2}\left(\mathrm{NO}_{3}\right)_{2}$ and exposure times in the experiment.

The impact of Uranium on the bioluminescent assay system can include a radiation component and a chemical one. To isolate the chemical component, we compared the effect of Uranium to that of model nonradioactive heavy metal - Europium. The effect of several concentrations of $\mathrm{Eu}\left(\mathrm{NO}_{3}\right)_{3}$ on the bacterial bioluminescence is demonstrated in Fig. 2(B). The bioluminescence kinetics was approximated with linear fit:

$$
I^{r e l}=-a \ln t+1
$$

Angular coefficients $a$ for of $\mathrm{UO}_{2}\left(\mathrm{NO}_{3}\right)_{2}$ and $\mathrm{Eu}\left(\mathrm{NO}_{3}\right)_{3}$ of two concentrations are presented in Table.

It is seen from the Table that $a$-values are of the same order for Uranium and Europium. This shows that effects of Uranium and Europium are similar. Hence, all the effects of $\mathrm{UO}_{2}\left(\mathrm{NO}_{3}\right)_{2}$ studied above can be ascribed to the chemical component.

It is known that humic substances serving as natural complexing agents are able to detoxify solutions of metallic salts (Takahashi et al., 1997; 

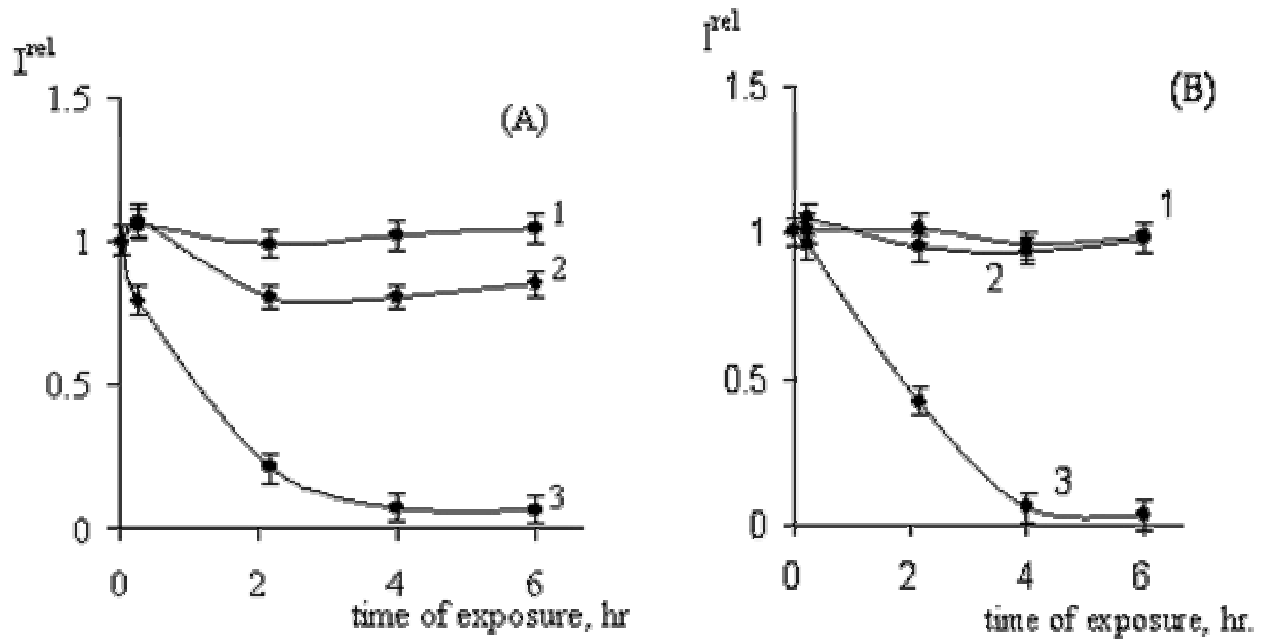

Fig. 2. Bioluminescent intensity $\left(\mathrm{I}^{\mathrm{rel}}\right)$ vs time of exposure ( $\mathrm{t}$, hours) in solutions of $\mathrm{UO}_{2}\left(\mathrm{NO}_{3}\right)_{2}(\mathrm{~A})$, and $\mathrm{Eu}\left(\mathrm{NO}_{3}\right)_{3}(\mathrm{~B})$. Concentrations of the salts: $1-10^{-11}, 2-10^{-7}, 3-10^{-3} \mathrm{M}$

Table. Angular coefficient $a$ and approximation values A in equation (1) in solutions of $\mathrm{UO}_{2}\left(\mathrm{NO}_{3}\right)_{2}$ and $\mathrm{Eu}\left(\mathrm{NO}_{3}\right)_{3}$

\begin{tabular}{c|cc|cc}
\hline Concentration, $\mathrm{M}$ & \multicolumn{2}{|c|}{$\mathrm{UO}_{2}\left(\mathrm{NO}_{3}\right)_{2}$} & \multicolumn{2}{c}{$\mathrm{Eu}\left(\mathrm{NO}_{3}\right)_{3}$} \\
\cline { 2 - 5 } & \multicolumn{1}{c|}{$A$} & 0,93 & $a$ & $A$ \\
\hline $10^{-3} \mathrm{M}$ & 0,17 & 0.97 & 0,13 & 0,94 \\
$10^{-5} \mathrm{M}$ & 0,02 & 0,01 & 0,71 \\
\hline
\end{tabular}

Provenzano et al., 2004). Detoxification ability of humic substances in solutions of $\mathrm{Am}\left(\mathrm{NO}_{3}\right)_{3}$ and $\mathrm{UO}_{2}\left(\mathrm{NO}_{3}\right)_{2}$ was studied using luminescent bacteria as assay system. Conditions of experiment (radionuclide concentration and incubation time) were chosen revealing time-decay of $I^{\text {rel }}$. For instance, Fig. 3 demonstrates detoxification of Americium solution $\left(10^{-10} \mathrm{M}, 3000 \mathrm{~Bq} / \mathrm{l}\right)$. It is seen that humic substances decrease time-decay of $I^{r e l}$, approaching it to control, thus decreasing toxicity of the radioactive solution.

We found that humic substances do not change time-decay of $I^{r e l}$ in solutions of uranyl under all conditions inhibiting bioluminescence (incubation time till $25 \mathrm{~h}$, and uranyl concentrations $10^{-3} \div 2 \cdot 10^{-7} \mathrm{M}$ ) (Fig.2 (A). Hence, these solutions are not detoxified at the conditions of the experiment.

\section{Conclusion}

Contributions of radiation and chemical components to the effect of the radionuclides on bacterial bioluminescence depend on specific radioactivity of the radionuclide. The effect of Uranium on bioluminescent bacteria is conditioned by chemical, but not radioactive properties of this radionuclide. The effect of Americium was due to its radioactive component only.

The effect of Uranium was found at higher concentrations $\left(>10^{-7} \mathrm{M}\right.$ or $\left.>0.3 \mathrm{~Bq} / \mathrm{l}\right)$ than that of Americium $\left(>10^{-11} \mathrm{M}\right.$ or $\left.>300 \mathrm{~Bq} / \mathrm{l}\right)$. The effect of Americium included activation and inhibition of bioluminescence at different times of exposure. 


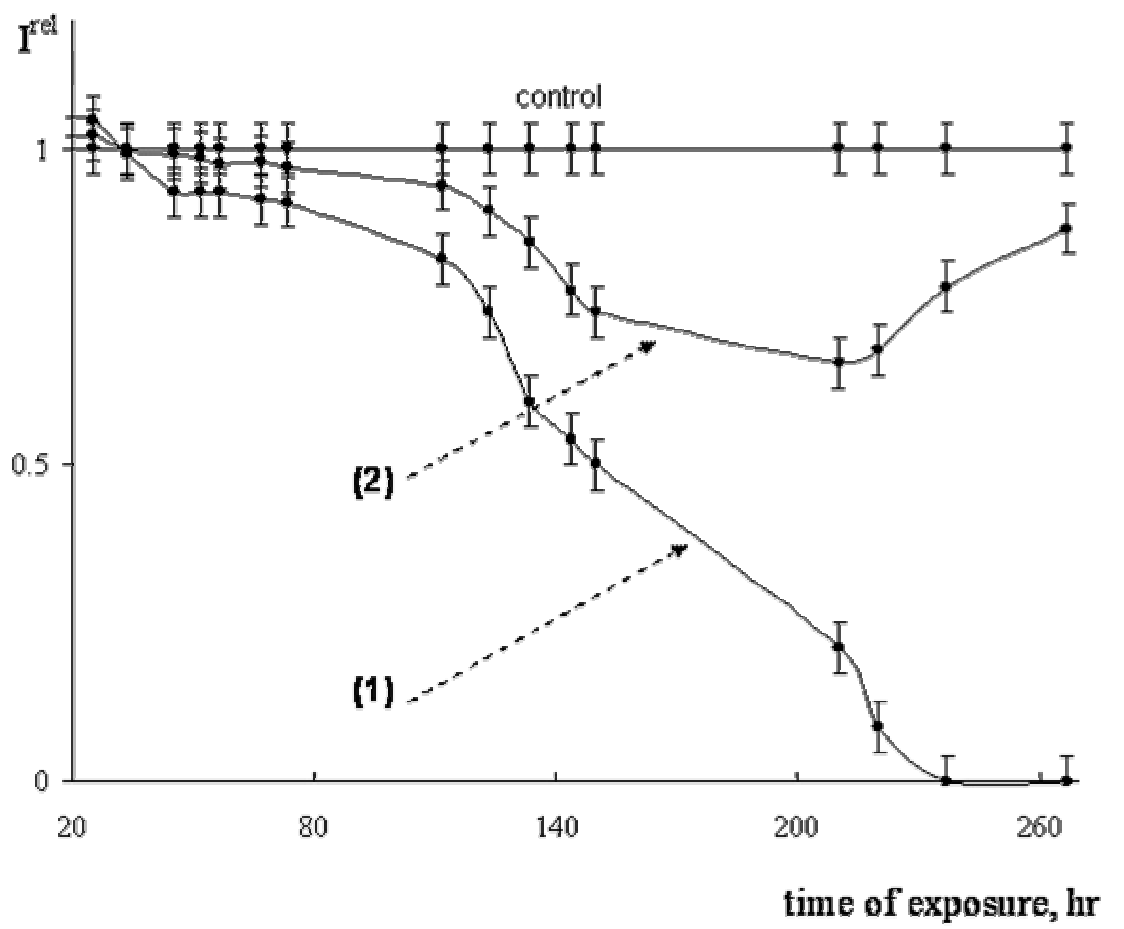

Fig. 3. Bioluminescent intensity ( $\left.\mathrm{I}^{\mathrm{rel}}\right)$ vs time of exposure ( $\mathrm{t}$, hours) in solutions ${ }^{241} \mathrm{Am}\left(\mathrm{NO}_{3}\right)_{3}\left(10^{-10} \mathrm{M}, 3000 \mathrm{~Bq} / \mathrm{l}\right)$ in the absence (1) and in the presence (2) of humic substances. Control - bioluminescent intensity in the absence of ${ }^{241} \mathrm{Am}\left(\mathrm{NO}_{3}\right)_{3}$

Only inhibition of bioluminescence was observed in the presence of Uranium. Humic substances $(\mathrm{C}$ $=0.25 \mathrm{mg} / \mathrm{ml}$ ) detoxified solutions of Americium and did not detoxify solutions of Uranium.

\section{Acknowledgements}

The work was supported by: Award No. RUX0-002-KR-06 of the U.S. Civilian Research \& Development Foundation (CRDF) and RF Ministry of Education and Science, BRHE
Program; Grant "Molecular and Cellular Biology", program of Russian Academy of Sciences; Grant of National Goals Program for 2007-2012, RF Ministry of Education and Science; Innovation program for young scientists of Siberian Federal University.

Authors are thankful to D.Stom for preparation of Humic substances.

\section{References}

Grabert E., Kossler F. (1997) About the effects of nutrients on the luminescent bacteria test. In: Hastings, J.W., Kricka, L.J., Stanley P.E. (eds.) Bioluminescence and Chemiluminescence. John Wiley \& Sons, Chichester, p.291-294.

Koterov A.N., Nikolsky A.V. (1999) Adaptation to irradiation in vivo. Radiatsionnaya biologiya. Radioekologiya 39: 648. (in Russia)

Kratasyuk V.A., Gitelson I.I. (1987) Use of bacterial bioluminescence and bioluminescent assay. Uspekhi mikrobiologii 21: 3-30. (in Russia) 
Kudryasheva N. Esimbekova E., Vetrova E., Kudinova I. (1998) Development of the bioluminescent bioindicators for analyses of pollutions, Field Analytical Chemical Technologies 2: 277-280.

Kudryasheva N., Vetrova E., Kuznetsov A., Kratasyuk V., Stom D. (2002) Bioluminescent assays: effects of quinones and phenols. Ecotoxicology and Environmental Safety 53: 221-225.

Kudryasheva N.S., Esimbekova E.N., Remmel N.N, Kratasyuk V.A., Visser A.J.W.G., van Hoek A. (2003) Effect of quinones and phenols on the triple enzymic bioluminescent system with protease. Luminescence 18: 224-228.

Kudryasheva N.S. (2006) Bioluminescence and exogenous compounds. Physico-chemical basis for bioluminescent assay. J. Photochem.Photobiol B, 1: 77-86.

Kuznetsov A.M., Rodicheva E.K., Shilova E.V. (1996) Bioassay based on lyophilized bacteria. Biotekhnologiya 9: 57-61. (in Russia)

Levinsky B. (2000) All about humates, Korf-Poligraf, Irkutsk, 71 p. (in Russia)

Lyutykh V.P., Dolgikh A.P. (1998) Clinical aspects of the effect of low-dose ionizing radiation on the human. Meditsinskaya radiologiya i radiatsionnaya bezopasnost 43: 28-34.

Min J., Lee C.W., Gu M.B. (2003) Gamma-radiation dose-rate effects on DNA damage and toxicity in bacterial cells. Rad. Environ. Biophys. 42: 189-192.

Natecz-Jawecki, G., Rudz, B., Sawicki, J. (1997) Evaluation of toxicity of medical devices using Spirotox and Microtox tests: I. Toxicity of selected toxicants in various diluents. Biomedical Materials Research 35: 101.

Nikolsky A.V., Koterov A.N. (1999) Radioadaptive response of mammalian cells. Meditsinskaya radiologiya i radiatsionnaya bezopasnost 44: 5-18. (in Russia)

Provenzano M., D’Orazio V., Jerzykiewiez M., Senesi N. (2004) Fluorescence behaviour of Zn and Ni complexes of humic acids from different source. Chemosphere 55: 885-890.

Roda A., Pasini P., Mirasoni M., Michchelini E., Guardigli M. (2004) Biotechnological application of bioluminescence and chemiluminescence. Trends in Biotechnology 22: 295.

Rozhko T.V., Kudryasheva N.S., Kuznetsov A.M., Vydryakova G.A., Bondareva L.G., Bolsunovsky A.Ya. (2007) Effect of low-level $\alpha$-radiation on bioluminescent assay systems of various complexity. Photochem. Photobiol. Sci. 6: 67-70.

Spitkovsky D.M. (1999) On some new biophysical and biological aspects of mechanisms under the impact of "low" and near-low doses of ionizing radiation on eukaryotic cells. Radiatsionnaya biologiya. Radioekologiya 39: 145-155. (in Russia)

Stom D.I., Geel T.A., Balayan A.E., Kuznetsov A.M., Medvedeva S.E. (1992) Bioluminescent method in studying the complex effect of sewage components. Arch. Environ. Contam. Toxicol. 22: 203-208.

Takahashi Y., Minai Y., Ambe S., Makide Y., Ambe F., Tominaga T. (1997) Simultaneous determination of stability constants of humate complexes with various metal ions using multitracer technique. Sci. Total Environ. 198: 61-71.

Wood K.V., Gruber M.G. (1996) Transduction in microbial biosensors using multiplexed bioluminescence. Biosensors and Bioelectronics 11: 207-214. 